\title{
PRESERVATIONAL CLIMATE CONDITIONING FOR ARTWORKS ON PAPER
}

\author{
UDC 003.2/.3:697
}

\author{
Ivan Mijailović ${ }^{1}$, Slobodan Radojković ${ }^{2}$ \\ ${ }^{1}$ University of Niš, Faculty of Occupational Safety in Niš, Serbia \\ ${ }^{2}$ University of Niš, Faculty of Arts, Serbia
}

\begin{abstract}
Artworks on paper include manuscripts, prints, drawings, collages, and paintings on paper. Their preservation requires strict values of microclimate parameters, in particular temperature, humidity, radiation and illumination. Maintenance of these parameters in exhibition spaces and storages is of vital importance for collection integrity. Paper as an art medium is particularly sensitive to these factors. Employment of HVAC (Heating, Ventilating and Air Conditioning) system is recommended in order to avoid unwanted fluctuations in microclimate conditions. Intelligent control system should be used for data acquisition and activation of HVAC system when needed. In that way, the live span of these sensitive artworks can be extended and preserved for future generations.
\end{abstract}

Key words: artwork on paper, preservation, indoor microclimate quality, HVAC system.

\section{INTRODUCTION}

Artworks on paper include manuscripts, prints, drawings, collages, and paintings on paper. Due to their sensitivity, these artworks require special attention of artwork conservation and preservation professionals. Preventive conservation is a specialty within the field of conservation as a profession, which aims to identify and reduce the potentially disruptive risks for cultural artifacts (in our case paper and parchment material) through the deliberate control of the conditions in which the subject is located. This prevents unnecessary damage and slows down the natural aging of cultural artworks. Proper and consistent implementation of preventive protection of cultural heritage minimizes the need for curative conservation and restoration. However, although accepted in theory, preventive conservation in practice has not reached the satisfactory level, primarily due to the lack of education in the area on one hand, and the lack of strategic plans at the state level. Although preventive measures are primarily aimed at preserving the physical

Received April 3, 2019 / Accepted April 23, 2019

Corresponding author: Ivan Mijailović

University of Niš, Faculty of Occupational Safety, Čarnojevića 10A, 18000 Niš, Serbia

E-mail: ivan.mijailovic@znrfak.ni.ac.rs 
integrity of museums and museum storages and archived material, they are not exclusively within the competence of the conservator, but should always be carried out by those who directly or indirectly come into contact with the material.

\section{Microclimate Parameters in MUSEUMS}

The most important parameters which must be strictly controlled within museum settings and storages are the air temperature, relative air humidity $(\mathrm{RH})$, particulate content and gaseous contaminants, radiation and illumination as well as adequate ventilation rate. HVAC Design Guidelines recommend maintaining the temperature between $18-24^{\circ} \mathrm{C}$ throughout the year, allowing seasonal fluctuations between the two extremes, but holding daily fluctuations to $\pm 2-3^{\circ} \mathrm{C}$.

Humidity is most often associated with an increased probability of bio-deterioration. Levels at 60\% Relative Humidity (RH) should be considered the threshold for damage. HVAC Design Guidelines recommend maintaining relative humidity between $40 \%$ and $55 \%$ throughout the year, allowing seasonal fluctuations between the two extremes, but holding daily fluctuations to $\pm 3 \%$.

Particulate content of museum air may also affect preservation. Particulates are common hosts for mold, are often abrasive, and may permanently soil collections. Particulates also increase user discomfort and increase maintenance costs. HVAC Design Guidelines recommend filtration of dust particulate to remove at least $50 \%$ of particulates using the ASHRAE Dust Spot Efficiency Test. On the other hand, conservation and preservation professionals recognized the following critical parameters.

\subsection{The air temperature}

Temperature and oscillations of temperature directly affect the preservation of all museum objects, and then, of course, those of paper. Higher temperatures stimulate and accelerate chemical reactions. For example, paper will oxidize heavily by heating, and it is very inflammable.

Higher temperatures accelerate the biological activity of many organisms, insects eat more, multiply faster, and molds grow faster. High temperatures cause brittleness and fracture of paper, especially those of wood. The adhesive material is also changing its structure depending on the temperature fluctuations.

Temperatures below $0^{\circ} \mathrm{C}$ cause water freezing. When water transforms from a liquid state to a solid, it increases volume which causes many consequences for all materials that contain water.

According to the general rule for the preservation of museum objects, the recommended temperature is $20-22^{\circ} \mathrm{C}$, which is also the temperature comfort zone for visitors and employees. However, for artworks on paper, preservation requirements are slightly different; the room temperature should be maintained between 17 and $19^{\circ} \mathrm{C}$, and some consider 20 , with temperatures not supposed to grow above $24^{\circ} \mathrm{C}$ [10]. Whenever the specific space is not frequently used by people, the temperature should be as low as possible, but still above $4^{\circ} \mathrm{C}$. 
To save artwork on paper, it is important to avoid sudden changes in temperature, which cause sudden expansion and shrinking of materials, and consequently the artwork destruction.

\subsection{Relative air humidity}

With changes in air temperature, the relative air humidity $(\mathrm{RH})$ varies. $\mathrm{RH}$ is the ratio of the amount of water vapor in the air at a certain temperature and the maximum amount of water which the air can contain at the same temperature. When $\mathrm{RH}$ is close to $100 \%$, or $100 \%$, condensation occurs on cold surfaces.

It is especially important to understand that the air at different temperatures can contain different amounts of water at the point of saturation. Warm air can contain more water than cold. For example, the $25^{\circ} \mathrm{C}$ air temperature can contain up to $24 \mathrm{~g} / \mathrm{m} 3(100 \%$ $\mathrm{RH})$ while the air at the temperature of $10^{\circ} \mathrm{C}$ can contain up to $9 \mathrm{~g} / \mathrm{m} 3(100 \% \mathrm{RH})$. The average value for paper should be between 40 and $50 \% \mathrm{RH}$, with a monthly oscillation of not more than $5 \%$. When water is lost, the paper shrinks and vice versa. Low RH causes drying of paper - glue, fillers and fibers, so the paper becomes brittle. At low RH paper releases water from its surface, then from its molecular structure, and eventually paper becomes fragile. Excessive RH stimulates and accelerates chemical reactions, creates unevenness, accumulates and causes the bulging of the paper.

$\mathrm{RH}$ greater than $70 \%$ stimulates infestation and increases insect activity, favoring the growth of molds and algae. The extremely high $\mathrm{RH}$ on some artworks on paper can weaken the painted layer and loosen its connection to the paper.

\subsection{Electromagnetic radiation}

Every electromagnetic radiation is detrimental to artwork, but the damage usually arises from UV, IR radiation and visible light. The artworks on paper are very sensitive to all types of radiation. It is therefore important to take all precautions that will reduce the exposure to radiation to the smallest possible extent.

\subsection{Infrared Radiation (IR) - infrared light}

This radiation is perceived as the heat which causes and accelerates thermo-chemical and physical-thermal reactions. Objects exposed to this radiation heat up, which means they change the volume and dehydrate. The paper loses elasticity and becomes brittle and fragile.

The heat is radiated by the sun, heating appliances, but also the light bulbs with Wolfram's thread, as well as other light sources, e.g. halogen lights.

Influence of IR is proportional to decreasing with distance from the source of radiation.

Artworks on paper must not be exposed to the direct influence of IR radiation. This means that they should not be near or above the heating appliances.

Preventive protection against IR radiation begins with the building and heating design. However, this is possible only when the exhibition space is designed from scratch. In the existing exhibition spaces, the walls on which the heating appliances are already mounted cannot be used as exhibition surfaces. Otherwise, the artworks will be exposed to the accelerated decay. 
All heating appliances which radiate direct heat should be avoided. All heating appliances such as heating panels, stoves and heat reflected appliances should be avoided in museum spaces. The suitable system is central heating ventilation and air conditioning (HVAC), with the minimal fluctuations of air temperature and minimal IR radiation.

\subsection{Ultraviolet (UV) Radiation - Ultra-Violet (UV) light}

UV radiation is invisible to the human eye, and we cannot even feel it as IR radiation. UV radiation effect can be favorable, but also dangerous to human health. Short wavelength possesses more energy than long one, so photo-chemical reactions are faster and more turbulent. That's why UV radiation is the most harmful for artwork; it causes more damage than visible light in a shorter time.

UV radiation is measured by instruments called UV monitor, UV radiometer, and UV data logger. The models can differ and are similar to the light intensity meters (illuminometers lx meters).

Ideally, in the exhibition spaces, there should be no UV radiation at all. This goal is difficult to achieve in the exhibition spaces, but it can be accomplished in storages. UV rays produced by artificial lights can be successfully avoided by the indirect illumination, by the employment of shades, etc.

The value of UV Radiation is expressed in $\mu \mathrm{W} / \mathrm{lm}$ (microwatt/lumen). The upper limit for gallery space is $75 \mu \mathrm{W} / \mathrm{lm}$ while the recommended level is less than 25 . The alternative measure unit is $\mathrm{mW} / \mathrm{m} 2$. The objects should not be exposed to more than $20 \mathrm{~mW} / \mathrm{m} 2$, (the recommended value is less than 6). When exposed to a light source, paper quickly turns yellow, become brittle and fragile, which is the consequence of photo-chemical reactions.

\subsection{Illumination}

Artifacts on paper must not be illuminated with more than $50 \mathrm{Lx}$. When exposed to direct light, color paper can easily fade. Drawings and pictures painted with some types of ink and pens can fade and change the color if exposed permanently to the radiation source. The same is applied to the watercolor paintings depending on the pigment which is used.

\subsection{Gaseous Contaminants}

Gaseous contaminants, such as nitrogen-oxides and sulfur-dioxide can attack organic materials by conversion to acids, while ozone is a powerful oxidant, severely damaging all organic material. Other gaseous pollutants, such as formaldehyde, may be emitted from storage cabinets, shelves or glues within the museum. HVAC Design Guidelines recommend filtration of gaseous contaminants to maintain preservation standards throughout the facility, coupled with localized auxiliary filtration with air purifiers in highly critical areas.

\subsection{Airflow}

Adequate ventilation rates are essential to avoid stagnant air and inhibit the growth of microorganisms. Ventilation is critically important for museums, since it not only ensures the health and wellbeing of staff and visitors but also helps to minimize the potential for mold outbreaks by providing adequate circulation of the air through high efficiency 
filters. Stagnant air can promote mold growth and should be correctly attended to in the HVAC design.

\section{HVAC SYSTEM DESIGN FOR THE MUSEUMS}

The preservation of the artworks on paper is a specific problem with strict requirements considering microclimate parameters. Being the most sensitive among the artworks, their preservation demands stable conditions which should be granted by adequate HVAC system design. The HVAC system must guarantee the control of the transient phenomena, the ambient microclimatic control ( $\mathrm{T}$ and $\mathrm{RH}$ ) and integration of the technology in the building structure. The control of the transient phenomena is strongly related to the variability of the thermal loads that the HVAC system must balance in operating time [7]. The variable presence of visitors and employees can cause significant and sudden changes of the environmental conditions; so the reaction of the HVAC system must be extremely quick in order to restore the design values of the thermal-hygrometric conditions for the conservation [4]. For example, Schito, et al. have tracked the changes of air temperature and $\mathrm{RH}$ during the operating hours of the museum and noticed that there is an increase in the air temperature of almost $6^{\circ} \mathrm{C}$ and $\mathrm{RH} 15 \%$ during the busiest working hours [9]. These are worrying results, having in mind that monthly variations of RH should not exceed 5\%. The outside thermal load, instead, changes more slowly because the layers of most buildings destined to museums (heavy structure) induce a high thermal inertia and then an attenuation of the instantaneous thermal gains: therefore, the HVAC system is able to keep the design conditions without significant indoor changes.

The adoption of adsorption dehumidification systems allows the reduction of the humidity also when the required dew point temperature is very low; that way, an easier handling of high latent loads is obtained. These systems are better in terms of hygienic characteristics because the absence of condensed water strongly reduces the presence of bacteria, fungi and microbes. Absorption dehumidification systems, instead, should be avoided, because of the potential risk of acid particles (i.e. chlorine solutions) or drops released in the air flow, with consequent damaging risk for the collections.

Because the goal is the strict control of the ambient microclimatic parameters, excessive amounts of outside air can be problematic in terms of cost-effectiveness. Even when freecooling is convenient, outside air can bring particles and gaseous pollution. So, the outside air should flow into the space in the minimum amount required to provide fresh air for occupants and to pressurize collection spaces.

Sensors, thermostats and humidistat must be located in the collection space, not in the return air stream. Temperature variation is usually preferable to prolonged humidity swings. This strongly affects control design, because conventional control systems treat temperature as the primary goal and humidity as supplementary [2]. 


\section{MONITORING EQUIPMENT}

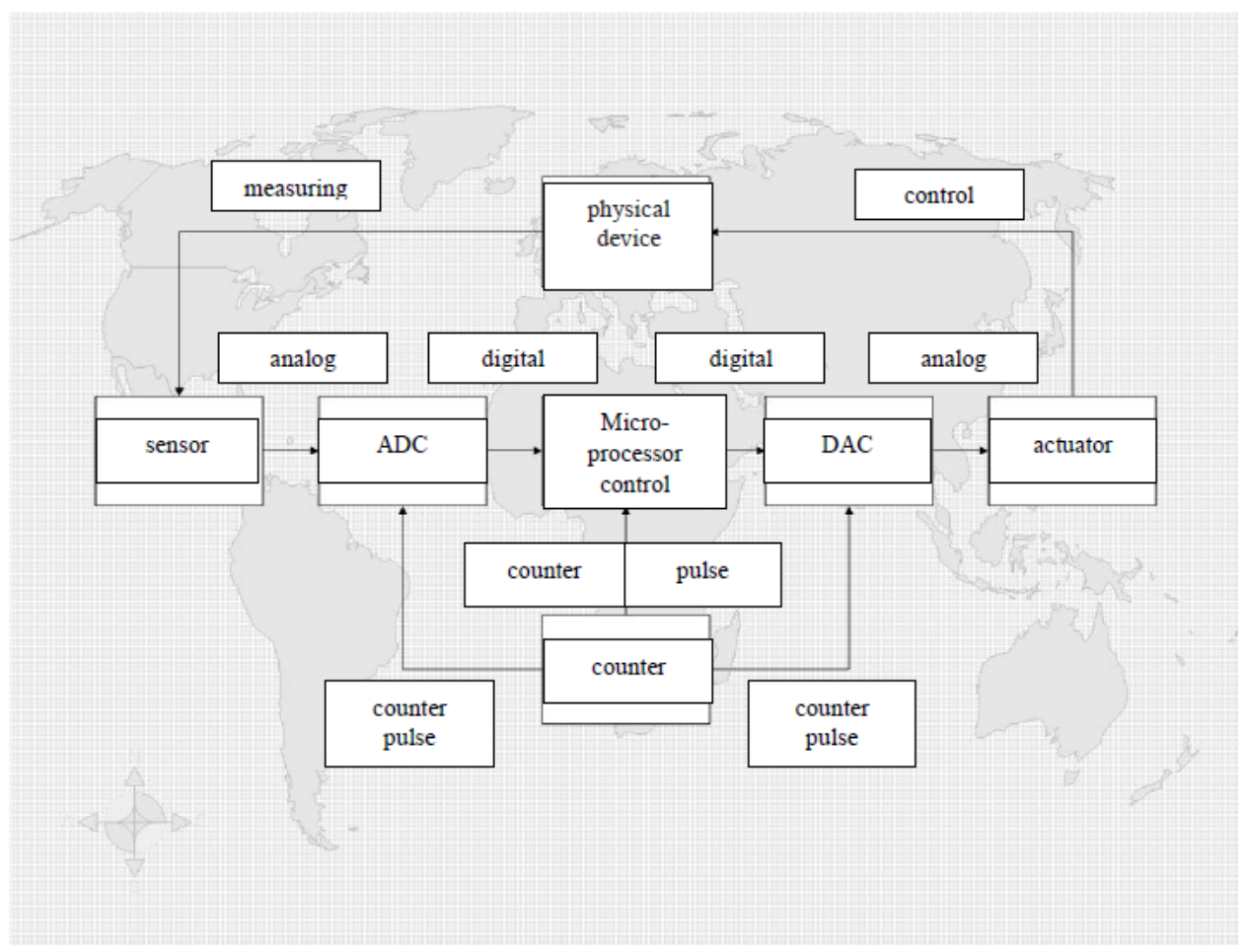

Fig 1 Microprocessor control system

One of the possible solutions which can be employed for microclimate conditions control in the exhibition area is an intelligent mechatronic system with integrated mechanical, electrical and computing components (see Fig. 1). The process of data acquisition of the system begins with the measurement of physical values by the sensor. The sensor has the ability to generate some form of a signal, usually an analogue signal in the form of a voltage level or a certain wavelength. This analogue signal is sent to the analog-to-digital converter (ADC). It is common to use a successive approximation, ADC mapping analog input signals to a digital output. This digital value is composed of a set of binary values called "bits" (often predefined as $0 \mathrm{~s}$ and $1 \mathrm{~s}$ ). A batch set is a decimal or hexadecimal number that a microcontroller can use. The microcontroller consists of microprocessor, memory and other connected devices. The program in the microprocessor uses the digital value together with other input data and the acquired values called calibration in order to determine the output commands. Like the microprocessor, these output data are in digital form and are represented by a set of bits. A digital-analog converter (DAC) is often used to convert digital values to an analog signal. Following this, an analog signal is used for actuators for controlling physical devices or affecting the physical environment. The sensor then performs new measurements and the process is repeated so that the control cycle is complete. Finally, the total operation time is synchronized using the counters. 


\section{CONCLUSION}

Maintenance of constant microclimate parameters in museums is of vital importance for collection integrity. Moreover, in spaces for exhibition of artworks on paper, microclimate parameters such as temperature, relative air humidity $(\mathrm{RH})$, particulate content and gaseous contaminants, radiations, as well as adequate ventilation rate should be strictly controlled. Paper as a medium is particularly sensitive to these factors and any fluctuations can be detrimental and cause decay of the artworks. Whenever possible and especially in the design of novel exhibition spaces, it is important to include HVAC in the design process. One of the possible solutions which can be employed for microclimate conditions control in the exhibition area is an intelligent mechatronic system with integrated mechanical, electrical and computing components. In that way, the live span of these sensitive artworks can be extended and preserved for future generations.

\section{REFERENCES}

1. Ayres J.M., Lau H., Haiad J.C.,1996, Energy impact of various inside air temperatures and humidities in a museum when located in five U.S. cities, ASHRAE Transaction, n.2, pp.100- 111.

2. ASHRAE, 2003, ASHRAE Handbook - HVAC Applications, Chapter 21, Museums, libraries, and archives, pp. 21.1-21.16.

3. Bovill C.,1988, Qualitative engineering, ASHRAE Journal, April, pp. 29-34.Hartman T., 1996, Library and Museum HVAC: New Technologies/New Opportunities -Heating/piping/air conditioning, part 1, n.4, pp. 57-60.

4. Hartman T., 1996, Library and Museum HVAC: New Technologies/New Opportunities -Heating/ piping/air conditioning, part 1, n.4, pp. 57-60.

5. Hartman T., 1996, Library and Museum HVAC: New Technologies/New Opportunities - Heating/ piping/air conditioning, part 2, n.5, pp. 63-73.

6. Lull W., Harriman L., 2001, Museums, Libraries \& Archives, Humidity control design guide for commercial and institutional buildings, ASHRAE, Chapter 23, pp. 334-358.

7. Mecklenburg M., Tumosa C., 1999, Temperature and relative humidity effects on the mechanical and chemical stability of collections, ASHRAE Journal, April, pp. 77-82. https://www.researchgate.net/ publication/298203283_Temperature_and_relative_humidity_effects_on_the_mechanical_and_chemical _stability_ of_collections

8. Giani E. et al, 2010, A museum storage area: microclimate and air quality short-term monitoringprogramme, E-preservation science pp. 55-58. http://www.morana-rtd.com/e-preservationscience/2010/Giani-14-052008.pdf

9. Shito E. et al, 2016, A proposal for new microclimate indexes for the evaluation of indoor air quality in museums, Buildings, pp. 1-15. https://doaj.org/article/dd9598c2daa54a128168c3c67be0a50b

10. Laszlo Ž., Dragojević A., 2010, Priručnik preventvne zaštite umjetnina na papiru, Crescat, Zagreb. 


\section{PREVENTIVNO KONDICIONIRANJE MIKROKLIMATSKIH PARAMETARA ZA UMETNIČKA DELA NA PAPIRU}

Umetnička dela na papiru su između ostalih rukopisi, grafike, crteži, kolaži i akvareli. Njihova preventivna zaštita zahteva veoma precizne vrednosti mikroklimatskih parametara, a posebno temperature, vlažnosti vazduha, zračenja i osvetljenosti. Održavanje ovih parametara u izložbenim prostorima i muzejskim depoima je od presudne važnosti za održivost kolekcija. Papir kao umetnički medijum je posebno osetljiv na ove faktore. Upotreba sistema ventilacije i klimatizacije HVAC (Heating, Ventilating and Air Conditioning) je preporučljiva, a u svrhu sprečavanja neželjenih fluktuacija mikroklimatskih parametara. Inteligentni sistemi kontrole bi trebalo da obavljaju poslove prikupljanja podataka o mikroklimatskim uslovima u izložbenim prostorima $i$ depoima i aktiviraju sistem za ventilaciju i klimatizaciju po potrebi. Na taj način, životni vek ovih osetljivih umetničkih dela bio bi produžen i očuvan za buduće generacije.

Ključne reči: umetnička dela na papiru, preventivna zaštita, kvalitet mikroklimatskih uslova, sistemi ventilacije i klimatizacije. 